\title{
Histamine Degradation by Diamine Oxidase, Lactobacillus and Vergibacillus halodonitrificans Nai18
}

\section{Aishath Naila ${ }^{1 *}$, Steve Flint ${ }^{1}$, Graham C Fletcher ${ }^{2}$, Phil Bremer ${ }^{3}$ and Gerrit Meerdink}

${ }^{1}$ Institute of Food Nutrition and Human Health, Massey University, Private Bag 11-222 Palmerston North, NZ

${ }^{2}$ Food Safety \& Preservation, New Zealand Institute for Plant \& Food Research Limited, Private Bag 92169, Auckland, NZ

${ }^{3}$ Department of Food Science, University of Otago, PO Box 56, Dunedin, NZ

${ }^{4}$ Department of Food Manufacture and Automation, University of Lincoln - Holbeach Campus, Park Road, Holbeach PE12 7PT, UK

\begin{abstract}
The aim of this work was to explore suitable methods (bacteria/enzyme) to degrade histamine as an alternative method for the control of histamine in food. Histamine degradation by bacteria was studied in trypticase soy broth containing $500 \mathrm{ppm}$ of histamine at $30^{\circ} \mathrm{C}$ for 9 days. The bacteria studied were Lactobacillus sakei (AGR 37, AGR 46, Lb 706), Arthrobacter crystallopoietes DSM 20117 and Vergibacillus halodonitrificans Nai18. All L. sakei strains reduced histamine to about $50 \%$ while $V$. halodonitrificans Nai18 degraded histamine by $30 \%$. A. crystallopoietes DSM 20117 did not degrade histamine. Diamine oxidase (DAO), however, degraded histamine (500 ppm) to an undetectable level $(<0.1 \mathrm{ppm})$ in the model system (buffer). DAO was more successful than the bacteria in reducing histamine in the preliminary trials, therefore, DAO was selected for further study in a food system, the tuna soup used to manufacture Rihaakuru, a fish paste product from the Maldives, containing $1 \%$ salt at a $\mathrm{pH}$ of 6.0 . The DAO degraded histamine in the tuna soup to an undetectable level, confirming the potential for DAO to reduce histamine during the manufacture of Rihaakuru. This enzyme may have potential to control histamine in other foods but different appropriate environmental conditions (eg levels of $\mathrm{pH}$ ) would need to be tested to determine their effect on the activity of DAO.
\end{abstract}

Keywords: Vergibacillus halodonitrificans Nai18; DAO; Histamine degradation; Lactobacillus sakei; Arthrobacter crystallopoietes; HPLC

\section{Introduction}

Scombroid poisoning is caused mainly by the consumption of fish, fish products and fermented foods that are processed under poor hygiene and/or stored at elevated temperatures. This allows the growth of histamine producing bacteria that may result in dangerous histamine levels (> $500 \mathrm{ppm}$ ) [1]. The symptoms of scombroid poisoning are urticaria, flushing, itching, vomiting, diarrhoea and nausea [2,3]. Histamine poisoning is increasing internationally in countries including the USA, Great Britain, Japan [4] and Taiwan [5]. Many incidents may be unreported as official records are not kept by all countries and many people do not report this illness. Traditional foods such as fish sauce from Korea and Malaysia [6,7], fermented fish paste from Taiwan [8,9], and a cooked fish paste (Rihaakuru) from the Maldives have been reported to contain high levels of histamine [10]. While Rihaakuru is generally stable in terms of bacterial deterioration [11], bacterial growth in the fish used to manufacture this product, has been speculated to be responsible for the high histamine levels in the product [10] as refrigeration is not widely available in the Maldives. In the absence of effective temperature control alternative methods are needed to control histamine levels in Rihaakuru, which continues to be a popular and widely consumed stable food. Two alternative control methods [12] that have the potential to be applied to the raw material extract (tuna soup) used to manufacture Rihaakuru, are the addition of microorganisms or enzymes that degrade histamine. The by-products of the histamine degradation are aldehyde, ammonia and hydrogen peroxide [13], as shown in reaction equation 1 .

$$
\text { R. } \mathrm{CH}_{2} \cdot \mathrm{NH}_{2}+\mathrm{H}_{2} \mathrm{O}+\mathrm{O}_{2} \rightarrow \mathrm{R} \cdot \mathrm{CHO}+\mathrm{NH}_{3}+\mathrm{H}_{2} \mathrm{O}_{2}
$$

Some bacteria have been reported to reduce histamine, including Staphylococcus carnosus FS19 and Bacillus amyloliquefaciens FS05 [14], Lactobacillus sakei [15], and Vergibacillus sp.SK33 [16]. Diamine oxidase (DAO) has been found to degrade histamine from fish slurry more effectively than histamine reducing bacteria [15]. DAO is an enzyme generally present in human intestines where it will degrade histamine taken with food. This suggests that the enzyme, DAO, is safe. However the efficacy of this naturally present enzyme must vary depending on the intake of histamine with high histamine intake resulting in illness [13].

In order to choose the most promising approach for histamine degradation, two different treatments, either histamine degrading bacteria or DAO were compared in preliminary trials. The most promising method could then be used for more comprehensive trials for the degradation of histamine in tuna soup used for the manufacture of Rihaakuru. In this preliminary study, the histamine degrading bacteria were tested in the TSB (Trypticase Soy Broth) because they grow best in this medium; therefore this was most likely to be optimal for histamine degradation by bacteria. The DAO was tested in buffer because it is reported to be the best medium for DAO activity [15,17].

\section{Materials and Methods}

\section{Materials}

All the bacterial species chosen for this study were based on the

${ }^{*}$ Corresponding author: Aishath Naila, Institute of Food Nutrition and Human Health, Massey University, Private Bag 11-222 Palmerston North, NZ, Tel: +960 7991969; E-mail: a_naila@hotmail.com

Received May 07, 2012; Accepted June 20, 2012; Published June 23, 2012

Citation: Naila A, Flint S, Fletcher GC, Bremer P, Meerdink G (2012) Histamine Degradation by Diamine Oxidase, Lactobacillus and Vergibacillus halodonitrificans Nai18. J Food Process Technol 3:158. doi:10.4172/2157-7110.1000158

Copyright: ( 2012 Naila A, et al. This is an open-access article distributed unde the terms of the Creative Commons Attribution License, which permits unrestricted use, distribution, and reproduction in any medium, provided the original author and source are credited. 
literature reports of their potential histamine degradation. Lactobacillus sakei strains (AGR 37, AGR 46, Lb 706) were isolates from dairy products kindly provided by Fonterra ${ }^{\mathrm{TM}}$ (Palmerston North, New Zealand). Arthrobacter crystallopoietes DSM 20117 was purchased from DSMZ (GmbH, Germany). Vergibacillus halodonitrificans Nai18 was isolated from Rihaakuru as described in our previous work [10]. Histamine dihydrochloride $\left(\mathrm{C}_{5} \mathrm{H}_{9} \mathrm{~N}_{3} .2 \mathrm{HCl}\right)$ as the source of histamine and $99 \%$ pure benzoyl chloride $\left(\mathrm{C}_{7} \mathrm{H}_{5} \mathrm{ClO}\right)$ were obtained from Acros Organics (New Jersey, USA). Salt ( $\mathrm{NaCl}$, Labserv) and hydrochloric acid ( $\mathrm{HCl}$, Labserv) were used to adjust the salt and $\mathrm{pH}$ of the tuna soup and were purchased from Biolab (Biolab (Aust) Ltd, Victoria, Australia). Sodium hydroxide $(\mathrm{NaOH})$ pellets were obtained from BDH Limited Poole England (Great Britain). Distilled water $\left(\mathrm{H}_{2} \mathrm{O}\right)$ was used to prepare all the solutions. Diamine oxidase (DAO: EC 1.4.3.6) from porcine liver $(0.18 \mathrm{unit} / \mathrm{mg}$ ) was obtained from Sigma-Aldrich (ST. Louis, USA).

Chilled yellowfin tuna (Thunnusalbacares) loins (4.84 kg) were purchased from Ocean Fisheries (Palmerston North, New Zealand) and transferred to the Food Technology Pilot Plant freezer $\left(-18^{\circ} \mathrm{C}\right)$ of Massey University until required to produce the tuna soup base for Rihaakuru. To obtain tuna soup from yellow fin tuna, the tuna were cooked in salt as described in our previous work [11].

\section{Histamine degradation by bacteria}

Five bacteria [Lactobacillus sakei (AGR46, AGR37, Lb 706), Arthrobactercrystallopoietes DSM20117, Vergibacillus halodonitrificans Nai18] were grown in trypticase soy broth (TSB) for $24 \mathrm{~h}$ at $30^{\circ} \mathrm{C}$, then $10 \%$ bacteria were inoculated into TSB containing histamine dihydrochloride $(500 \mathrm{ppm})$. The samples were incubated at $30^{\circ} \mathrm{C}$ for $216 \mathrm{~h}$. Samples were taken at 0, 24, 50, 96 and $216 \mathrm{~h}$. Two millilitres of samples were stored at $-80^{\circ} \mathrm{C}$ until histamine analysis. A temperature of $30^{\circ} \mathrm{C}$ was selected to represent the ambient temperature in the Maldives, and the selected bacteria grow readily at this temperature. Therefore, if the bacteria degrade histamine at this temperature the tuna soup temperature can be easily set by leaving the soup until it cools down and add the bacteria, because the controlled temperature storage is generally unavailable to local producers of Rihaakuru. The $\mathrm{pH}$ and salt concentration may affect the rate and extent of histamine degradation but both would be difficult to control in the Maldives. For these trials, TSB was approximately $\mathrm{pH} 6$, and a salt concentration of $1.5 \%$, close to that of tuna soup. The TSB was selected because it is the standard medium for the growth of the bacteria used in this study.

\section{Histamine degradation by DAO}

DAO activity test: The DAO activity was initially tested at optimum conditions ( $\mathrm{pH} 7.0$ and $37^{\circ} \mathrm{C}$ ) based on Dapkevicius et al. [15], with little modification. Briefly, 633.5 units/L enzymes (units calculated based on the manufacture's label; 0.18 unit $/ \mathrm{mg}$ ) were added into $0.5 \mathrm{M}$ phosphate buffer containing $0.05 \mathrm{~g} / \mathrm{L}$ ( $50 \mathrm{ppm}$ ) histamine dihydrochloride. The samples were incubated at $37^{\circ} \mathrm{C}$ and agitated at $100 \mathrm{rpm}$ for $5 \mathrm{~h}$ (Model Amper Chart Multitron II, Infors HT, Total Lab Systems Ltd, Christchurch, New Zealand). Samples $(2 \mathrm{~mL})$ were taken at $0,0.5,1,3$, and $5 \mathrm{~h}$ and immediately boiled for $30 \mathrm{~min}$. The samples were stored at $-80^{\circ} \mathrm{C}$ until histamine analysis.

Selection of DAO concentration: The ability of DAO to degrade histamine was tested at several levels (between 633.5 to 2534 units/L) to obtain a suitable concentration to degrade $500 \mathrm{ppm}$ of histamine by at least $50 \%$. A $0.5 \mathrm{M}$ phosphate buffer model system was prepared by adding $500 \mathrm{ppm}$ of histamine at $\mathrm{pH} 6$ and salt $1 \%$ and this was incubated for $10 \mathrm{~h}$ at $37^{\circ} \mathrm{C}$ and agitated at $100 \mathrm{rpm}$ (Model Amper Chart Multitron II, Infors HT, Total Lab Systems Ltd, Christchurch, New Zealand) after adding the enzyme. The $\mathrm{pH}$ and salt concentrations used were selected based on the value of these parameters present in the tuna soup used in the manufacture of Rihaakuru since the authors are interested in applying this to the manufacture of Rihaakuru. The typical levels of $\mathrm{pH}$ and salt for Rihaakuru are between 5.6 to 6.1 and 1-3\%, respectively [11]. The initial enzyme concentration and the experimental procedure were selected based on the work of Dapkevicius et al. [15], with a few modifications. Samples were taken at 0, 0.5, 1, 3, 5 and $10 \mathrm{~h}$ and immediately boiled for $30 \mathrm{~min}$ to inactivate the enzyme. The samples were transferred to a $-80^{\circ} \mathrm{C}$ freezer until histamine analysis.

Histamine degradation in buffer and tuna soup: For the experiments in buffer and tuna soup, DAO at 2534 units/L was used, based on earlier preliminary experiments $\bigotimes$. The experimental procedures were similar those in the above section.

\section{Histamine analysis}

Histamine analysis was carried out by the methods of Hwang et al. [18] and Kung et al. [19] with slight modifications as described in our previous work [10]. Histamine degradation was monitored by measuring the percentage of histamine reduction in the samples over time.

Preparation of histamine standards: A series of histamine standards (0-500 ppm) were prepared by weighing appropriate amounts of histamine dihydrochloride and dissolving in $0.1 \mathrm{M}$ hydrochloric acid. The standards were derivatized using benzoyl chloride and analyzed using High Performance Liquid Chromatography (HPLC). The data were used to plot a calibration curve for histamine quantification.

Derivatization: Samples and histamine standards $(2 \mathrm{ml})$ were derivatized by adding $1 \mathrm{ml}$ of $2 \mathrm{M}$ sodium hydroxide followed by $10 \mu \mathrm{l}$ benzoyl chloride, and stored at $30^{\circ} \mathrm{C}$ for $40 \mathrm{~min}$. Benzoylation was stopped by mixing with $2 \mathrm{ml}$ of saturated sodium chloride, and histamine was extracted with the addition of $3 \mathrm{ml}$ of diethyl ether followed by mixing in a mixer (Griffin flask shaker, Kumar Group, Delhi, India) for $5 \mathrm{~min}$, and centrifugation at $3000 \mathrm{x} \mathrm{g}$ for $15 \mathrm{~min}$ (Eppendorf Centrifuge 5702, (Eppendorf, Hamburg, Germany)). The organic layer was then dried by passing through a nitrogen stream and the residue dissolved in $1.5 \mathrm{ml}$ of HPLC grade methanol. The samples were mixed using the mixer (Griffin flask shaker, Kumar Group, Delhi, India) for $30 \mathrm{~s}$ followed by centrifugation for $5 \mathrm{~min}$ at $3000 \mathrm{x} \mathrm{g}$. The samples and the standards were filtered through a nylon membrane filter $(0.2 \mu \mathrm{m}$, Startorium Stedim Biotch, Germany) into HPLC vials. A $20 \mu$ volume was injected into the HPLC system described below, run for $28 \mathrm{~min}$, and monitored at a $254 \mathrm{~nm}$. Each assay was carried out in triplicate.

HPLC system: Histamine was analyzed by an HPLC system that consisted of a Waters 2487 Dual $\lambda$ Absorbance detector (Global Sience) at $254 \mathrm{~nm}$, Alliane Waters 2690 separation model (Global science), using a LiChrospher $100 \mathrm{RP}-18$ reversed-phase column $(5 \mu \mathrm{m}, 125 \mathrm{x}$ $4.6 \mathrm{~mm}$, Merck, Ltd., New Zealand). The gradient elution program was set at a flow rate of $0.8 \mathrm{ml} / \mathrm{min}$ and the column oven temperature was set at $25^{\circ} \mathrm{C}$ throughout the analysis. The gradient program started at 50:50 (methanol/water) for $0.5 \mathrm{~min}$, linearly increasing to $85: 15$ for the next $6.5 \mathrm{~min}$, held constant at $85: 15$ for $5 \mathrm{~min}$ and decreased back to 50:50 over the next $2 \mathrm{~min}[18]$ 
Data analysis: For statistical analysis Minitab statistical software (Version 15, Minitab Ltd., UK) was used. General Linear Model (GLM) was used to obtain least square means and standard error of the mean, and the Tukey test was used to do a pairwise comparison for the times and treatments. Significance was tested at $\mathrm{p}<0.05$. Graphs were drawn using Sigma plot (Version 12.0, Aspire Software International, Virginia, USA).

\section{Results}

\section{Histamine degradation by bacteria}

Arthrobacter crystallopoietes DSM 20117 did not produce a significant reduction in histamine $(\mathrm{p}>0.05)$ (Figure 1). However, the L. sakei strains (AGR46, AGR37, Lb706) and V. halodonitrificans Nai18 (Figure 1) degraded histamine in TSB containing 500 ppm of histamine by approximately $40-50 \%$, and $30 \%$ respectively and this degradation was statistically significant $(\mathrm{p}<0.05)$. Most of the reduction in histamine occurred within the first $50 \mathrm{~h}$. In comparison to L. sakei strains AGR 37 and 46 and $V$. halodonitrificans, the histamine degradation by L. sakei Lb706 ( $\mathrm{p}<0.05)$ was significantly larger. There was no significant difference $(\mathrm{p}>0.05)$ in histamine degradation between the L. sakei strains AGR 37 and 46 to that of $V$. halodonitrificans. The Lactobacillus strains were previously shown not to produce histamine (data not shown). Due to inability to degrade all the added histamine, the bacteria were not used to degrade histamine in the tuna soup. DAO was examined as another possible method to degrade histamine.

\section{Histamine degradation by DAO}

DAO activity test: DAO (633.5 units/L) degraded histamine dihydrochloride $(0.050 \mathrm{~g} / \mathrm{L})$ to an undetectable level $(<0.1 \mathrm{ppm})$ in 0.5 $\mathrm{M}$ phosphate buffer ( $\mathrm{pH} 7.0$ ) when incubated at $37^{\circ} \mathrm{C}$ with agitation at $100 \mathrm{rpm}$ for $5 \mathrm{~h}$. The DAO degraded $100 \%(0.05 \mathrm{~g} / \mathrm{L})$ of the histamine within $1 \mathrm{~h}$ of incubation.

Selection of DAO concentration: DAO at 2534 units/L degraded $500 \mathrm{ppm}$ of histamine in $0.5 \mathrm{M}$ phosphate buffer ( $\mathrm{pH}$ 6) containing $1 \%$ salt to an undetectable level $(<0.1 \mathrm{ppm})$ when incubated for $10 \mathrm{~h}$ at $37^{\circ} \mathrm{C}$ and agitating at $100 \mathrm{rpm}$. Therefore, for subsequent experiments, a concentration of 2534 units/L DAO was used.

Degradation of histamine in buffer and tuna soup using DAO: DAO degraded all the histamine $(500 \mathrm{ppm})$ in buffer therefore was selected for further study in tuna soup used to manufacture Rihaakuru. In the tuna soup, DAO behaved as it did in the buffer, where histamine (500 ppm) was also degraded to undetectable levels $(<0.1 \mathrm{ppm})$ at $\mathrm{pH} 6$ and $1 \%$ salt and incubated for $10 \mathrm{~h}$ at $37^{\circ} \mathrm{C}$, agitated at $100 \mathrm{rpm}$ (Figure 2). A control test involved the tuna soup without the addition of DAO to ensure no histamine was produced during the $10 \mathrm{~h}$ incubation. There was no significant difference $(\mathrm{p}>0.05)$ between the time of treatment in the buffer control (without DAO), and the time of treatment in the soup control though the graph shows some fluctuation. Histamine degradation by DAO in buffer was not significant between 0 to $1 \mathrm{~h}$ but between 1 to $10 \mathrm{~h}$ the degradation was highly significant ( $\mathrm{p}<0.0003)$. DAO activity was almost as affective in tuna soup as in the buffer although up to the first $5 \mathrm{~h}$ of incubation, the rate of degradation was slightly slower in the tuna soup than in the buffer, but this difference was not significant $(p>0.05)$. Tuna soup without added DAO showed slight auto-degradation of histamine (approximately 25\%) after $5 \mathrm{~h}$ of incubation, but this was not significantly different $(p>0.05)$ compared to the control.

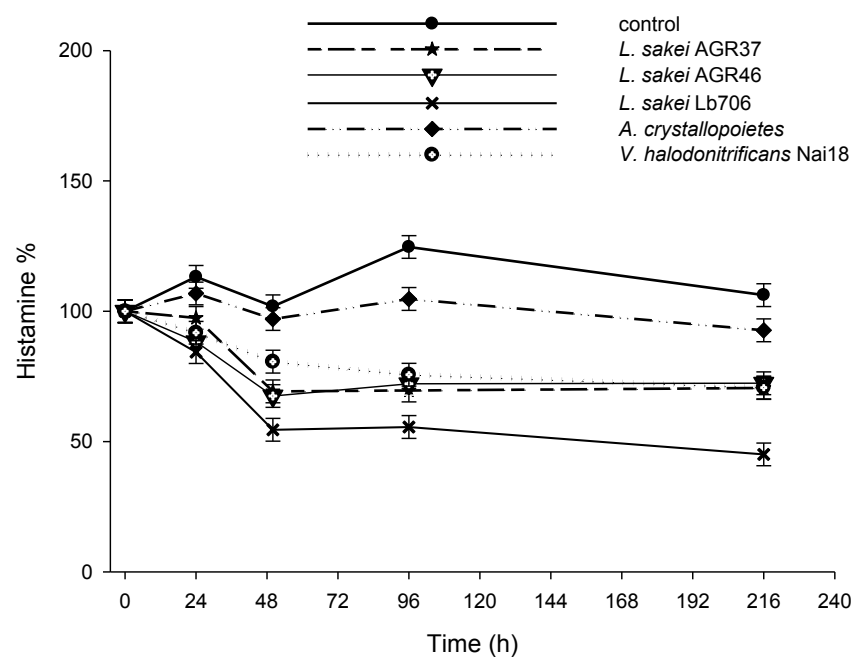

Figure 1: Histamine degradation by bacteria, Lactobacillus sakei (AGR 37 46 and Lb 706), Arthrobacter crystallopoietes DSM 20117 and Vergibacillus halodonitrificans Nai18. The bacteria were grown in TSB containing $500 \mathrm{ppm}$ histamine for $24 \mathrm{~h}$ at $30^{\circ} \mathrm{C}$. Error bars representing mean standard error $(\mathrm{n}=3)$.

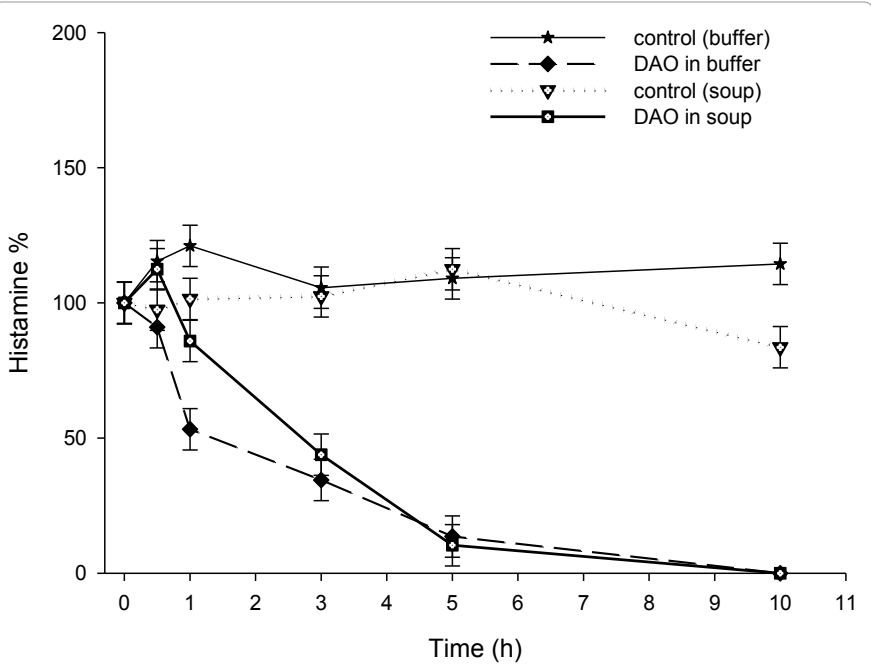

Figure 2: Histamine degradation ( $500 \mathrm{ppm})$ by DAO (2534 units/L) in $0.5 \mathrm{M}$ phosphate buffer and tuna soup under $\mathrm{pH} 6$ and salt $1 \%$ incubated at $37^{\circ} \mathrm{C}$ and agitated at $100 \mathrm{rpm}$ for $10 \mathrm{~h}$. Error bars represent standard error of mean $(n=6)$.

\section{Discussion}

A. crystallopoietes DSM 20117 inability to degrade histamine was interesting as DAO isolated from A. crystallopoietes KAIT-B-007 had previously been reported to degrade histamine by $100 \%$ [7]. Possibly A. crystallopoietes DSM 20117 may not possess the DAO enzyme or the enzyme may be inactive. Although some bacterial species have the ability to degrade histamine, not all the strains of the same species are able to degrade histamine [20]. It would be interesting to test the ability of A. Crystallopoietes KAIT-B-007 rather than using the isolated DAO enzyme. Unfortunately, we could not obtain this bacterium and therefore selected another strain for testing.

Histamine degradation by L. sakei strains was expected since this species has been reported to reduce histamine in food [15,21,22] 
Citation: Naila A, Flint S, Fletcher GC, Bremer P, Meerdink G (2012) Histamine Degradation by Diamine Oxidase, Lactobacillus and Vergibacillus halodonitrificans Nai18. J Food Process Technol 3:158. doi:10.4172/2157-7110.1000158

Page 4 of 4

Interestingly, the results using V. halodonitrificans Nai18 isolated from Rihaakuru [10] are similar to those of Yongsawatdigul et al. [16] using $V$. halodonitrificans SK33 isolated from Thai fish sauce, which showed a $50 \%$ reduction in histamine. Most of the reduction in histamine in both $L$. sakei strains and $V$. halodonitrificans occurred within the first $50 \mathrm{~h}$ because the bacteria may have reached stationary phase and viable cells may have started to die beyond the $50 \mathrm{~h}$.

In summary, the bacteria used in this study reduced the amount of histamine by a maximum of $50 \%$. This is not sufficient to ensure food safety therefore the use of these bacteria ability to degrade histamine in food was not investigated further

DAO degraded histamine to an undetectable level $(<0.1 \mathrm{ppm})$ in buffer, thus was selected to apply to tuna soup. Histamine autodegradation in tuna soup in our study agrees with Dapkevicius et al. [15] where histamine auto-degraded in fish slurry used for the manufacture of animal feed. The only study of DAO use in a food system was in animal feed [15]. No studies had applied DAO to a food for human consumption therefore we do not have a literature to further support our work. No data is available on the recommended use of DAO in food, as this is the first study using DAO to treat food for human consumption. However, the enzyme is unlikely to cause any harmful effects as the tuna soup is boiled following treatment, inactivating the enzyme. DAO has also been used to treat fish slurry for animal feed with no harmful effects reported [15].

This is the first study on the use of DAO to degrade histamine in tuna soup used to manufacture food (Rihaakuru) for human consumption. This is a preliminary study that showed DAO's potential to reduce histamine in food. To fully explore the effectiveness of DAO under variable $\mathrm{pH}$ and salt concentrations found in tuna soup, a statistically designed experiment, such as central composite design (CCD) is required. Initially such a study could use a controlled buffer system and then be repeated in the tuna soup.

In summary, DAO has potential to reduce histamine in food. Further work is required to investigate the activity of DAO at different $\mathrm{pH}$ and salt levels of tuna soup used to manufacture Rihaakuru or other foods.

\section{Conclusion}

Bacterial strains were shown to be able to degrade histamine only by $30-50 \%$ in TSB containing $500 \mathrm{ppm}$ of histamine. This would not be suitable for treating food therefore no further work was carried out on these strains. DAO, however was able to reduce histamine to an undetectable level $(<0.1 \mathrm{ppm})$ in a laboratory buffer and was therefore selected to study in food system (tuna soup used to manufacture Rihaakuru). The results in the tuna soup were similar to those in the buffer. However, this is a preliminary study showing the potential of the DAO to degrade histamine in food used for human consumption. Determining the activity of DAO under different $\mathrm{pH}$ and salt concentrations would be useful in applying to different foods as well as different batches of tuna soup that may vary in their $\mathrm{pH}$ and salt composition.

\section{Acknowledgement}

We thank Fonterra ${ }^{\mathrm{TM}}$, Palmerston North, and New Zealand for providing us some bacterial cultures. The authors thank New Zealand Development Scholarship (NZDS) for their financial support.

\section{References}

1. Shalaby AR (1996) Significance of biogenic amines to food safety and human health. Food Res Int 29: 675-690.

2. Silva TM, Sabaini PS, Evangelista WP, Gloria MBA (2011) Occurrence of histamine in Brazilian fresh and canned tuna. Food Control 22: 323-327.

3. Arnold SH, Brown WD (1978) Histamine toxicity from fish products. Adv Food Res 24: 113-154.

4. Tao Z, Sato M, Zhang H, Yamaguchi T, Nakano T (2011) A survey of histamine content in seafood sold in markets of nine countries. Food Control 22: 430-432.

5. Hwang DF, Chang SH, Shiau CY, Cheng CC (1995) Biogenic amines in the flesh of sailfish (Istiophorus platypterus) responsible for scombroid poisoning J Food Sci 60: 926-928.

6. Moon JS, Kim Y, Jang KI, Cho KJ, Yang SJ, et al. (2010) Analysis of biogenic amines in fermented fish products consumed in Korea. Food Sci Biotechnol 19: $1689-1692$

7. Zaman MZ, Bakar FA, Selamat J, Bakar J (2010) Occurrence of biogenic amines and amines degrading bacteria in fish sauce. Czech J Food Sci 28 440-449.

8. Fardiaz D, Markakis P (1979) Amines in fermented fish paste. J Food Sci 44 1562-1563.

9. Tsai YH, Lin CY, Chien LT, Lee TM, Wei Cl, Hwang DF (2006) Histamine contents of fermented fish products in Taiwan and isolation of histamineforming bacteria. Food Chem 98: 64-70

10. Naila A, Flint S, Fletcher GC, Bremer PJ, Meerdink G (2011) Biogenic amines and potential histamine - Forming bacteria in Rihaakuru (a cooked fish paste). Food Chem 128: 479-484.

11. Naila A, Flint S, Fletcher GC, Bremer PJ, Meerdink G (2011) Chemistry and microbiology of traditional Rihaakuru (fish paste) from the Maldives. Int J Food Sci Nutr 62: 139-147.

12. Naila A, Flint S, Fletcher G, Bremer P, Meerdink G (2010) Control of biogenic amines in food-existing and emerging approaches. J Food Sci 75: R139-R150.

13. Blaschko H (1974) The natural history of amine oxidases. Rev Physiol Biochem Pharmacol 70: 83-148.

14. Zaman MZ, Abu Bakar F, Jinap S, Bakar J (2011) Novel starter cultures to inhibit biogenic amines accumulation during fish sauce fermentation. Int $\mathrm{J}$ Food Microbiol 145: 84-91

15. Dapkevicius MLNE, Nout MJR, Rombouts FM, Houben JH, Wymenga W (2000) Biogenic amine formation and degradation by potential fish silage starter microorganisms. Int J Food Microbiol 57: 107-114

16. Yongsawatdigul J, Rodtong S, Raksakulthai N (2007) Acceleration of Thai fish sauce fermentation using proteinases and bacterial starter cultures. J Food Sci 72: M382-M390.

17. Bardsley WG, Crabbe MJ, Shindler JS (1973) Kinetics of the diamine oxidase reaction. Biochem J 131: 459-469.

18. Hwang DF, Chang SH, Shiua CY, Chai T (1997) High-performance liquid chromatographic determination of biogenic amines in fish implicated in food poisoning. J Chromatogr B Biomed Sci Appl 693: 23-29.

19. Kung HF, Chien LT, Liao HJ, Lin CS, Liaw ET, et al. (2008) Chemica characterisation and histamine-forming bacteria in salted mullet roe products. Food Chem 110: 480-485.

20. Sekiguchi Y, Makita H, Yamamura A, Matsumoto K (2004) A thermostable histamine oxidase from Arthrobacter crystallopoietes KAIT-B-007. J Biosci Bioeng 97: 104-110.

21. Bover-Cid S, Izquierdo-Pulido M, Vidal-Carou MC (2001) Effectiveness of a Lactobacillus sakei starter culture in the reduction of biogenic amine accumulation as a function of the raw material quality. J Food Prot 64: 367-373.

22. Spicka J, Kalač P, Bover-Cid S, Křižek M (2002) Application of lactic acid bacteria starter cultures for decreasing the biogenic amine levels in sauerkraut Eur Food Res Technol 215: 509-514. 